\title{
新しい光感受性物質meta-tetra(hydroxyphenyl)-chlorin(m-THPC)の 生体内分布に関する研究
}

\author{
筒井英光、會沢勝夫*、奥仲哲弥、渋谷 洋、イリアル・X*、古川欣也、山田公人、酒井治正、 \\ 小中千守、加藤治文 \\ 東京医科大学外科第一講座、*同第二生理
}

BIODISTRIBUTION AND PHOTODYNAMIC POTENCY OF m-THPC

Hidemitsu Tsutsui, Katsuo Aizawa*, Tetsuya Okunaka, Hiroshi Shibuya, llyal Xiahedin*, Kinya Furukawa, Kimito Yamada, Harumasa Sakai, Chimori Konaka, Harubumi Kato

Department of Surgery, * Physiol, Tokyo Medical College

\begin{abstract}
Photofrin is the only photosensitizer which has been given governmental approval and is currently put to clinical use. However, the fact that Photofrin is not a single compound, that the absorption at over $600 \mathrm{~nm}$ is extremely low and that there is the possibility of skin photosensitivity are a few of the specific problems that have become an issue. For more effective clinical application, second-generation sensitizers such as Mono-L-aspartyl chlorin $\mathrm{e}^{6}$ and ALA are being developed, moreover meta-tetra(hydroxyphenyl)-chlorin (m-THPC) is evaluated as one of the most promising photosensitizers. In Europe, Phase I study of $\mathrm{m}$-THPC has already proceeded, although there are many unacknowledged facts such as the biodistribution of the drug. As regards to studies in Japan, no published results have been reported. The accumulation of $\mathrm{m}-\mathrm{THPC}$ on the tumor and the normal internal organs were measured by a fluorescence analyzing microscope system.

$1 \times 10^{6}$ Meth-A fibrosarcoma cells were transplanted into the right hind legs of 4 week old male BALB/c mice (fed on chlorophyll free food). Approximately one week after transplantation, a tumor measuring about $10 \mathrm{~mm}$ in diameter and about $5 \mathrm{~mm}$ in height was developed. After an intravenous injection of $\mathrm{m}-\mathrm{THPC}$ at a dose of $1 \mathrm{mg} / \mathrm{kg}$, the normal internal organs and the tumor were extracted from the body at $24,48,72,96,120$ hours. M-THPC which was accumulated in each of the internal organs was excited with $420 \mathrm{~nm}$ and its fluorescence image was recorded.

In comparison with the other internal organs, the fluorescence in the tumor showed the maximum amount continuously after 48 hours after administration. The highest intensity of fluorescence in the tumor was observed 24 hours after administration, decreasing with the lapse of time but still after 120 hours, $70 \%$ of the fluorescence observed at the highest intensity retained. The fluorescence in the skin showed the same intensity as in the tumor after 24 hours administration, but decreased after 48 hours showing $80 \%$ of the fluorescence intensity compared with the tumor. This ratio of tumor to skin retained until 120 hours. The fluorescence in the liver showed approximately the same intensity as the muscle at 24 hours after administration. The fluorescence could not be identified after 48 hours, but after 72 hours and 96 hours fluorescence was visible but also weak. The fluorescence intensity in the muscle retained until after 72 hours but decreased to half at 96 hours and retained its intensity even after 120 hours. The ratio of the fluorescence intensity of tumor to muscle was approximately 5 to 1 until after 72 hours, subsequently increasing to 10 to 1 after 96 hours. The fluorescence in the brain could not be observed at either point.
\end{abstract}

In conclusion, after 24 hours administration, each internal organ showed the highest accumulation of $\mathrm{m}$-THPC, followed by a very slow decrease, resulting to only the slightest change in biodistribution from after 96 to 120 hours.

\section{I. 緒言}

Photofrinを光感受性物質として用いたエキシ マダイレーザーによる光線力学的治療法(PDT)は 平成6年11月に愿生省の認可を受け、新しい癌治
療法としての地位が確立されつつある1。しかし、

Photofrin注単一の化合物ではないこと、へモグ

ロビンの吸収带を避けることの出来る $600 \mathrm{~nm}$ 以

上での吸収が小さいこと、皮處の光過敏性を生 
ずることなどの問題を持っている2。ここれらの諸問

題を解決すべく、Mono-L-aspartyl chlorin $e^{63)}$ 、 ALA ${ }^{4)}$ 等の第2世代の腫激親和性光感受性物質が開 発されているが、クロリン系の光感受性物貿であ る meta-tetra(hydroxyphenyl)-chlorin(mTHPC)も有望な物質の1つである。 $\mathrm{m}-\mathrm{THPC}$ 既 にヨーロッパにおいて、Phase I studyが開始さ れているが5、本剤の生体内分布など不明な点は多 く、本邦での報告もない。我々はm-THPCの癌お 上び正常䁍器への集積を手術顕微鏡営光画像解析 システムによって観察した。

\section{II. 研究方法}

1. 実䮦動物

4週踣のBALB/C雄性マウス(17〜20g)の右大腿 部皮下にMeth - A 線維肉腫細胞 $1 \times 10^{6}$ 個を移植し、 約 1 週間で腫晹径 $8 \sim 10 \mathrm{~mm}$ 、高さ $5 \mathrm{~mm}$ となった担 癌マウスを作製した。

2. 光感受性物質 (m-THPC)

本研究で使用した $\mathrm{m}$ - THPC(Scotia Pharmaceuticals Ltd, Guild ford, UK)はクロ リン䍗の周辺にフェノール基が4つ付いた權造であ り、分子量は680.76である(Fig.1)。

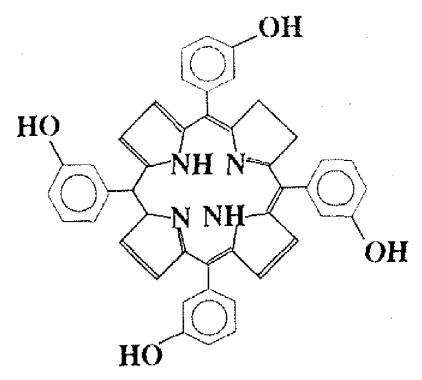

Fig. 1 Chemical Structure of $m$-THPC

\section{3. 実䮦方法}

$\mathrm{m}-\mathrm{THPC}$ を担癌マウスの尾静脈より体重 $1 \mathrm{~kg}$ あ たり $1 \mathrm{mg}$ 投与し、投与後 $24 、 48 、 72 、 96 、 120$ 時 間の各時点でエーテル麻酔下に犠牲死させ、種々 正常組織および腫瘟を摘出した。それぞれの $\mathrm{m}$ THPCを波長 $420 \mathrm{~nm}$ で励起した蛍光画像を手術顯
微鏡営光画像解析システムを用いて観察すると共 に、その蛍光強度を測定し蛍光強度の桧量線に対 応させ集積状態を比較した。

4. 手術影微鏡蛍光画像解析システム

手術営光顁微鏡(TOPCON.OMS -600)を改造し てシステムを作製した(Fig.2)。水銀ランプ光を間 腔ファイバーに導入し、420nmのバンドパスフィ ルターにて波長を選択し、m-THPCの励起に用い た。各組織に集積したm-THPCの表面蛍光は $550 \mathrm{~nm}$ 以下の波長をカットするハイパスフィルタ ーにより励起光の入力を除き、モノクロCCDカメ ラによって撮影した。映像はS-VHSビデオで記録 し、その蛍光画像はMediaGrabber2.2を用いてコ ンピューターに取り込み、NIH Image1.57で解析

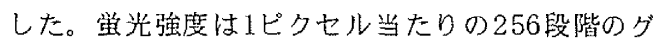
レ一值の平均として示した。

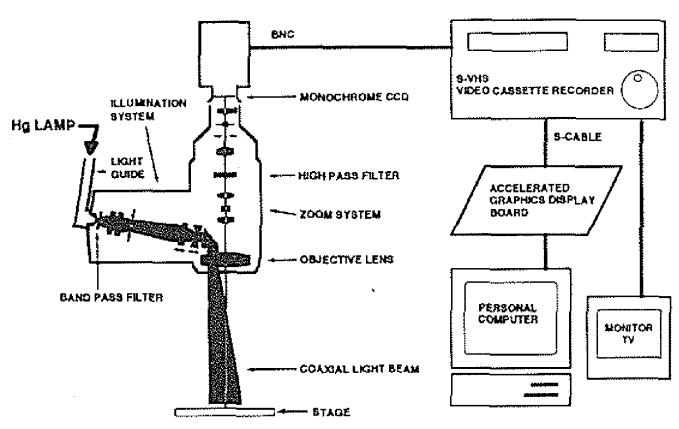

Fig.2 手術顕微鏡监光画像解析システム

III. 研究結果

1. 吸収および営光スペクトル測定 m-THPC、Photofrin、ヘモグロビンの吸収スベ クトルを示す(Fig.3)。m-THPCの溶媒は99.6\%エ タノール2gとポリエチレングリコール400 3gを蒸 留水で $10 \mathrm{ml}$ と希䣋したものを用いた。Photofrin はPBS中のものを示す。m-THPC溶液中の㖟収带 は420nmのSoret帯、519、545、597、651nmの Q带にそれぞれピークを示す。PhotofrinはPBS中 において、へモグロビンへの吸収の少ない $600 \mathrm{~nm}$

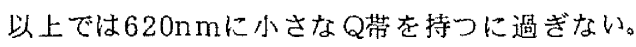
対してm-THPCは650nm付近にPhotofrinと比べ、 
約8倍の大きな吸収带を持つ。これはPDTを行う際 にヘモグロビンの吸収帯を避けることが出来ると 同時に励起効率が高い為に有利であることを示し ている。

$\mathrm{m}$-THPC溶液をSoret带の $420 \mathrm{~nm}$ で励起したと きの営光スペクトルを示す(Fig.4)。スペクトルは 単峰性であり、ピーク蛍光波長は652nmであった。

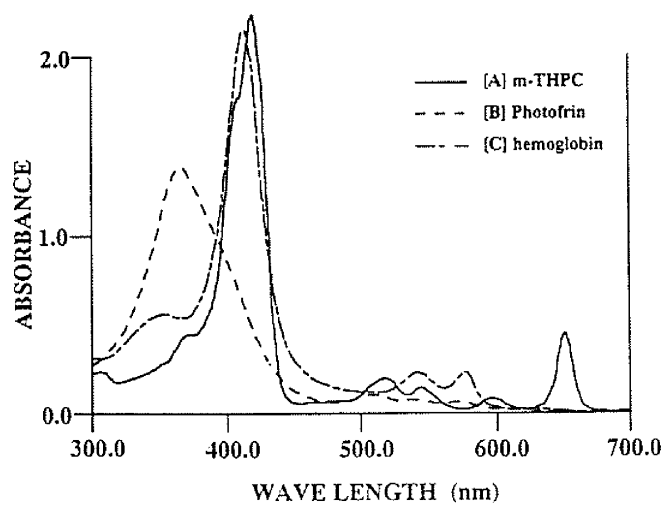

Fig. 3 The Absorption Spectra of Photosensitizers

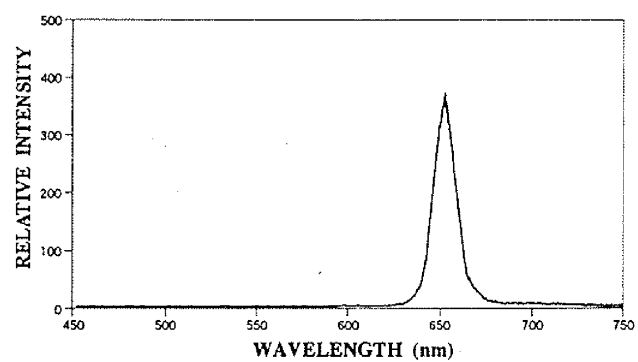

Fig.4 m-THPC FLUORESCENCE

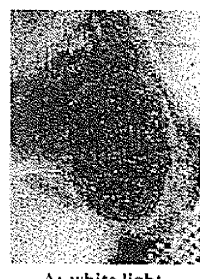

A: white light

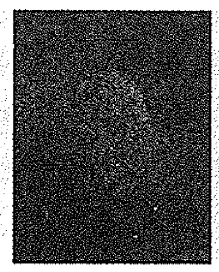

B: surface fluorescence $\$ 8$ hours after administration of $1 \mathrm{mg} / \mathrm{kg} \mathrm{m}$-THPC

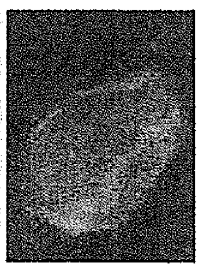

C: section fluorescence
写真1 TUMOR IMAGES

\section{2. 省光観察}

パソコン内に取り込んだ腫燩の画像を示す(写真 1)。マウス右後足の移植腫瘍の白色光における画 像をAに、同部位の営光画像をBに示した。腫檫に 集䆅した $\mathrm{m}-\mathrm{THPC}$ 蛍光が認められる。また、摘 出した腫湟の割面の蛍光画像をとに示した。

3. 蛍光スペクトルによる経時的䁍器集樌状態の 解析

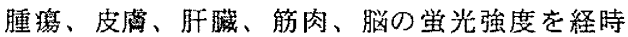
的に示す(Fig.5)。

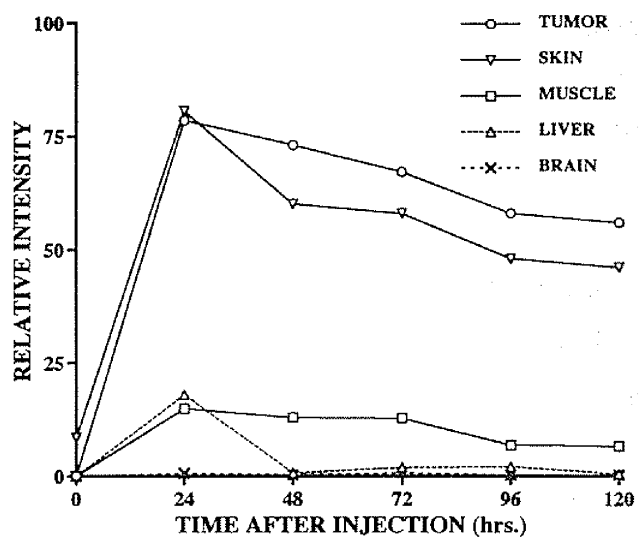

Fig.5 m-THPC DISTRIB UTION

m-THPC投与後の時間を横朝に、监光强度を縦軸 に示した。投与前における各蔵器の蛍光は自家蛍 光を示して㧍り、皮葻のみで認められた。 $\mathrm{m}$ THPCの営光は投与後 48 時間以後、いずれの時点 においても他臟器と比べ腫铬に高く観察された。 腫瑒の巣光強度の最高值は投与後24時間で生じ、 時間経過と共に減少したが、120時間後においても 最高値の約70\%の蛍光を認めた。皮原の蛍光強度 は投与後 24 時間で腫場と同程度に認められたが、 48時間以後は減少し、腫㿑の約 $80 \%$ の蛍光値を示 し、この比率は 120 時間後まで変わらなかった。肝 睵の営光は投与後 24 時間で筋肉とほぼ同じ強度で 観察され、48時間後では観察されず、再び72時間、 96時間後に小さな蛍光として観察された。㳙肉の 
蛍光強度は72時間後まではほぼ同じ值を示したが、 96時間では約半分に減少し、120時間後も変わら なかった。腫演と筋肉の蛍光強度の比をとると、 72 時間後までは約 5 倍、96時間以後が約 10 倍であ った。眇の営光は、いずれの時点においても観祭 されなかつた。

IV. 考察

吸収スペクトル測定の結果より、m-THPCの最 長波長吸収帯は651nmにあり、Photofrinの最長 吸収ピークに比べ $31 \mathrm{~nm}$ 程、與波長側にシフトして いた。また、m-THPCの最長波長での吸光度は Photofrinの8倍以上であった。これは癌組織内の 血流中のへモグロピンの吸収帯を避けることが出 来るという点、より長波長側での励起が可能な為、 樑い組織漫達性を持つレーザー波長を使用でさる という点、また吸収が大きい為、励起效率が良い という点で、PDTに際し、Photofrinよりも有利 である可能性を示している。

担澏マウスを用いたm-THPCの生体内分布の奏 験において、48時間以後はいすれれの時点において も、他の缄器と比べ腫瘍は高い集積状態を認めた。

我々は皮䇠の蛍光をマウスの毛の自家喾光の影 響を除く為、切除した皮盧を皮下側より観祭した か゚、皮下脂肪織へのm-THPCの集積があり、毛剃 门在完全に行った皮憈の表面営光よりは高く測定 されていた。

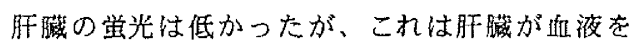
多く含む臟器であり、今回の実験が $420 \mathrm{~nm}$ 版起で あることより、レーザー光がへモグロビンに吸収 されてしまった為であると考えられる。また、48 時間後には認められなかった肝臟の営光は72、96 時間後において観察された。これはm-THPCの生 体内分布において、肝㖑に集䆏後、胆道系を経て 晹管から排泄される間にその一部が小腸で再吸収 され肝臟に戻るという晹肝循環の関与が推測され る。

脳の蛍光はいずれの時点においても観察されな かったことより、m-THPCがBBB(血液一脳関門) を通過しない薬凮であることが示された。
以上より、m-THPCは投与後24時間で各藏器に 最も高い集積を示した後、紘やかに減少するが、 96 時間から120時間後にかけては生体内分布の変 化は少ないことが示㖫された。しかし、有效性と 選択性を鑑みたPDTの最適施行時期の決定には今 後の研究が必要である。

\section{V. 文献}

1) H.Kato, et al. Photodynamic Therapy for Cancers - A Clinical Trial of Porfimer Sodium in J ap an ,J pn.J.Can cer. RES. 84, $1209-1214$, Nov em ber 1993

2) T.Katsumi, K.Aizawa, H.Kato, et al. Photodynamic Therapy Using a Diode Laser with Mono-Laspartyl Chlorin e6 for Implanted Fibrosarcoma in Mice, Jpn.J.Cancer. RES. 85, 1165-1170, November, 1994

3) K.Aizawa, T. Okunaka, H.Kato, et al. Localization of Mono-Laspartyl Chlorin e6 in Mouse Tissues, Photochemistry and Photobiology Vol.46,No. 5,789-793, 1987

4) J.C.Kennedy, R.H.Pottier, et al. Endogenous protoporphyrin IX,a clinically useful photosensitizer for photodynamic therapy, J.Photochem. Photobiol.B , Vol.14, 275-292, 1992.

5) H-B.Ris, H.J.Altermatt, B.Nachbur, J.C.M.Stewart, Q.Wang, C.K.Lim,R. et al. Effect of drug-Light Interval on PDT with $m-T H P C$ in malignant mesothelioma, Int.J. Cancer,53, $141-146,1993$. 